\title{
Comparative Flood Tolerance of Birch Rootstock
}

\author{
Thomas G. Ranney and Richard E. Bir \\ Department of Horticultural Science, Mountain Horticultural Crops Research and Extension Center, \\ North Carolina State University, 2016 Fanning Bridge Road, Fletcher, NC 28732-9216 \\ Additional index words. Betula nigra, Betula papyri fera, Betula pendula, Betula platyphylla var. japonica 'Whitespire', \\ carbon exchange rate, gas exchange, hypoxia, inundation, photosynthesis, waterlogging
}

\begin{abstract}
The potential for enhancing flood tolerance of birches by using better adapted rootstock was evaluated. Survival, growth, and physiological responses were compared among flooded and nonflooded container-grown Japanese birch (Betula platyphylla var. japonica Hara. 'Whitespire') trees grafted onto each of four rootstock: paper birch (B. papyrifera Marsh), European birch (B.pendula Roth.), river birch (B. nigra L.), and 'Whitespire' Japanese birch. Separate studies were conducted in Fall 1991 and Spring 1992. Results showed no consistent differences in net photosynthesis $\left(P_{n}\right)$ or survival among nonflooded plants regardless of rootstock or season, nor, were any symptoms of graft incompatibility evident. Flooding the root system for as long as $\mathbf{4 4}$ days revealed considerable differences among the four rootstock, with similar trends for fall and spring. Plants on river birch rootstock typically had one of the highest $P$ rates and stomatal conductance (g,) and, in certain cases, greater mean shoot growth rates and survival of plants subjected to prolonged flooding. Although plants with European birch rootstock had survival rates similar to those of plants with river birch rootstock, plants on European birch rootstock had lower $P_{n}$ under prolonged flooding, fewer late-formed roots, lower root-tip density after flooding, more abscissed leaves, and greater inhibition of shoot growth of plants flooded the previous fall. Paper and Japanese birch rootstock were most sensitive to flooding and had the lowest survival rate after flooding. However, plants on paper birch rootstock were the only plants whose $P_{n}$ did not increase significantly when flooding ended; they had the most abscissed leaves during spring flooding and the greatest inhibition of shoot growth in the spring after flooding the previous fall. The four rootstock ranked from most to least flood tolerant were river > European > Japanese > paper.
\end{abstract}

The genus Betula includes species found over a broad range of divergent habitats varying in hydrology and ranging from upland, alpine sites to wet bottomlands (Harlow et al., 1979; Hasselkus, 1984; Weaver, 1978). Birch species native to more upland sites, such as yellow birch (B. alleghaniensis Britt.), paper birch, and Japanese birch, can be more sensitive to root-zone flooding than species native to bottomland sites, such as river birch (McKim et al., 1975; Norby and Kozlowski, 1983; Tang and Kozlowski, 1982, 1983; Tsukahara and Kozlowski, 1986).

Plant responses to flooding typically vary with duration, season. and tolerance to the stress. Reductions in stomatal conductance $\left(\mathrm{g}_{\mathrm{s}}\right)$ and net photosynthesis $\left(\mathrm{P}_{\mathrm{n}}\right)$ are often early and sensitive indicators of plant strain in response to flooding (Andersen et al., 1984; Larson et al., 1991; Sojka and Stolzy, 1980). Prolonged flooding often inhibits shoot growth and induces leaf senescence and can compromise plant growth and survival (Pereira and Kozlowski, 1977; Tsukahara and Kozlowski, 1986). Considering the sequence and diversity of responses to flooding, it is often desirable to study a variety of growth and physiological responses during flooding that occurs in different seasons to assess a plant's response and shown relative tolerance to flooding adequately.

Research on drought resistance of birches has found 'Whitespire' Japanese birch to be more drought resistant than several other birch species including river, paper, and European birches (Ranney et al., 199 1). However, 'Whitespire' Japanese birch has also been

Received for publication 19 Apr. 1993. Accepted for publication 5 Aug. 1993. The work reported in this publication was supported in part by the North Carolina Agricultural Research Service (NCARS), Raleigh; Evergreen Nursery Co., Sturgeon Bay, Wis.; and the nursery industry through contributions to the Horticultural Research Institute, Washington, D.C. Use of trade names in this publication does not imply endorsement by the NCARS of products named nor criticism of similar ones not mentioned. We thank J.C. Raulston for his advice and cooperation and gratefully acknowledge the technical assistance of Everett Whitman and station personnel. The cost of publishing this paper was defrayed in part by the payment of page charges. Under postal regulations, this paper therefore must be hereby marked advertisement solely to indicate this fact. reported to be intolerant of flooding, as indicated by slow growth, plant decline, or both on poorly drained soils (Hasselkus, 1984). Grafting 'Whitespire' onto an appropriate rootstock could create a more adaptable tree by combining the drought resistance of the 'Whitespire' scion with a rootstock more tolerant of flooding. Because many birch species are important nursery or forestry crops, abetter understanding of the flood tolerance of various birch species and their suitability as rootstock would help select and improve birches for various climates. The purpose of this research was to evaluate the relative flood tolerance of four birch taxa when used as rootstock for 'Whitespire' birch scions.

\section{Materials and Methods}

Plant material and handling. 'Whitespire' Japanese, river, and paper birch were acquired from Evergreen Nursery (Sturgeon Bay, Wis.). European birch was acquired from Shannon Nursery(Marshall, N.C.). The 30- to 45-cm-high seedlings were grown in 3.8-liter plastic containers with a medium of 2 sandy loam (previously fumigated with methyl bromide) $: 1$ perlite $(\mathrm{v} / \mathrm{v})$. The medium was amended with $2.4 \mathrm{~kg}$ dolomite $/ \mathrm{m}^{3}$, resulting in a final $\mathrm{pH}$ of 5.8 . Plants were moved into a glass-covered greenhouse located at the Mountain Horticultural Crops Research Station, Fletcher, N. C., in February 1991. Once buds of the rootstock began to swell, dormant 'Whitespire' birch scions were grafted onto the aforementioned rootstock using a side graft and tied with a budding rubber, and the graft union was painted with a latex-based grafting sealer. Tops of the understock were then pruned to $\approx 25 \mathrm{~cm}$ high. Day and night greenhouse temperatures were maintained at $\approx 13 \mathrm{C}$ for 1 month, at which time the remaining portion of the understock was removed. Trees were transplanted on 1 June 1991 into 19-liter plastic containers filled with the medium previously described.

Fall study. Plants were moved into a greenhouse covered with a double layer of clear polyethylene and treatments began on 21 Aug. 1991. The treatment design was a two (flooded or control) $x$ four (taxa of rootstock) factorial arranged in a randomized com- 
plete-block design with 10 replications per factorial combination. Flooding was imposed on individual plants by placing a plant's container in another similar container lined with a polyethylene bag to prevent drainage. Containers were flooded and the water level was maintained at $\approx 3.5 \mathrm{~cm}$ above the root crown. Nontflooded trees served as controls and were irrigated daily. The flooding stress was relieved on 10 Oct. 1991 after 44 days of flooding. Midday air temperature and relative humidity (measured between 1200 and $1400 \mathrm{HR}$ ) during flooding averaged $27 \mathrm{C}$ and $60 \%$, respectively.

Leaf gas exchange and the number of abscissed leaves were recorded during flooding and the week after flooding ended. $\mathrm{P}_{\mathrm{n}}$ and $\mathrm{g}_{\mathrm{s}}$ rates and photosynthetically active radiation [PAR (400 to 700 $\mathrm{nm})$ ] were measured between 1030 and $1400 \mathrm{HR}$ with a portable gasexchange system (model LI-6200; LI-COR, Lincoln, Neb.). One leaf (third to fifth most recently matured) was measured per plant. Gas exchange was measured for $25 \mathrm{see}$, with $\mathrm{CO}_{2}$ initially at $330 \mathrm{ppm}$. The air flow through the desiccant was regulated to maintain the cuvette vapor pressure similar to that of ambient greenhouse conditions. Mean cuvette temperatures and vapor-pressure deficits, averaged over all sampling dates, were $30.6 \mathrm{C}$ and $2.65 \mathrm{kPa}$, respectively. Supplemental lighting was provided with a halogen lamp to ensure a minimum PAR of $1200 \mu \mathrm{mol} \cdot \mathrm{m}^{-2} \cdot \mathrm{s}^{-1}$ at the leaf surface.

Plants were moved outdoors in mid-October and over-wintered in an unheated polyethylene-covered greenhouse. Plants were returned to the heated greenhouse on $13 \mathrm{Feb} .1992$ and pruned to standardize each plant to five branches, each with five visible buds. Lengths of the longest three shoots (current season's growth) on each plant were measured on 30 Mar. 1992. Plant survival was also assessed at this time.

Spring study. Plants used as controls in the Fall 1992 flooding experiment were subsequently used in a second study to evaluate responses to flooding imposed early in a growing season. The experimental treatments and design were similar to the fall flooding experiment, except that there were five replicate plants for each factorial combination. Flooding began on 31 Mar. 1992 and continued until 11 May 1992 for a total of 43 days of flooding. Midday air temperature and relative humidity (measured between 1200 and 1400 нг) during flooding averaged 28C and 45\%, respectively. Leaf gas exchange, lengths of the three longest shoots per plant, and number of abscissed leaves were recorded during flooding and for 10 days after flooding ended. Leaf gas exchange was measured as described for the fall study. Mean cuvette temperatures and vapor pressure deficits, averaged over all sampling dates, were $30.9 \mathrm{C}$ and $2.94 \mathrm{kPa}$, respectively. Midday leaf water potentials were determined on the same leaves immediately after leaf gas exchange was measured on 1 May 1992 (day 33 of the study period) using a pressure vessel (plant moisture status console; Soil Moisture Equipment Corp., Santa Barbara, Calif.). The number of late-formed roots visible on the stem of the understock was recorded at the end of the 43-day flooding period on 11 May 1992. The number of actively growing root tips $(>0.5 \mathrm{~mm}$ in diameter) in a 3-cm-wide strip spanning the diameter of the bottom of the root mass in a random orientation were counted on 26 May 1992, 15 days after flooding ended.

Data from both studies were subjected to an analysis of variance for continuous responses. Significant differences among means were determined using least significant difference $(P \leq 0.05)$ comparisons. Chi-square tests were performed on survival data.

\section{Results}

Fall study. $\mathrm{P}_{\mathrm{n}}$ rates of the control plants decreased slightly during the study, but there were no consistent differences in $\mathrm{P}_{\mathrm{n}}$ among the graft combinations (Fig. 1A). Flooding resulted in a gradual decrease in $\mathrm{P}_{\mathrm{n}}$ for all plants during the first 23 days of the study. Paper birch, however, had a significantly lower $\mathrm{P}_{\mathrm{n}}$ than some or all of the other plants on days 3 and 10 (Fig. 1B). After 23 days, $\mathrm{P}_{\mathrm{n}}$ stabilized and remained low for all flooded plants, except for plants on river birch rootstock, which typically maintained significantly higher $\mathrm{P}_{\mathrm{n}}$ rates until flooding ended. Once flooding ended, plants on paper birch rootstock showed no signs of recovery, while $\mathrm{P}_{\mathrm{n}}$ of the other plants increased, and plants on river birch rootstock improved the most.

The trend in $\mathrm{g}_{\mathrm{s}}$ was similar to that of $\mathrm{P}_{\mathrm{n}}($ Fig. $2 \mathrm{~A}$ and B). For the control plants, $\mathrm{g}_{\mathrm{s}}$ fluctuated somewhat from day to day, but gradually decreased during the study (Fig. 2A). Stomatal conductance was similar among plants with different rootstock except that plants on European birch rootstock had a lower $g_{s}$ than some of the other graft combinations on several occasions. Stomatal conductance of flooded plants decreased in the first 23 days of flooding and then remained low for the duration of flooding.

Some leaves abscissed from the control plants (Fig. 3A). Although plants on river birch rootstock did not lose as many leaves early in the treatment, there was no difference in the total number of abscissed leaves at the end of the study between these and the control plants. The flooded plants with paper, European, and Japanese birch rootstock lost leaves during flooding, whereas plants with river birch rootstock lost no more leaves than the control plants (Fig. 3 A and B).

No late-fonned roots were observed on the stem of the rootstock for any of the graft combinations at any time during the fall study.

Many flooded plants were severely defoliated at the end of the
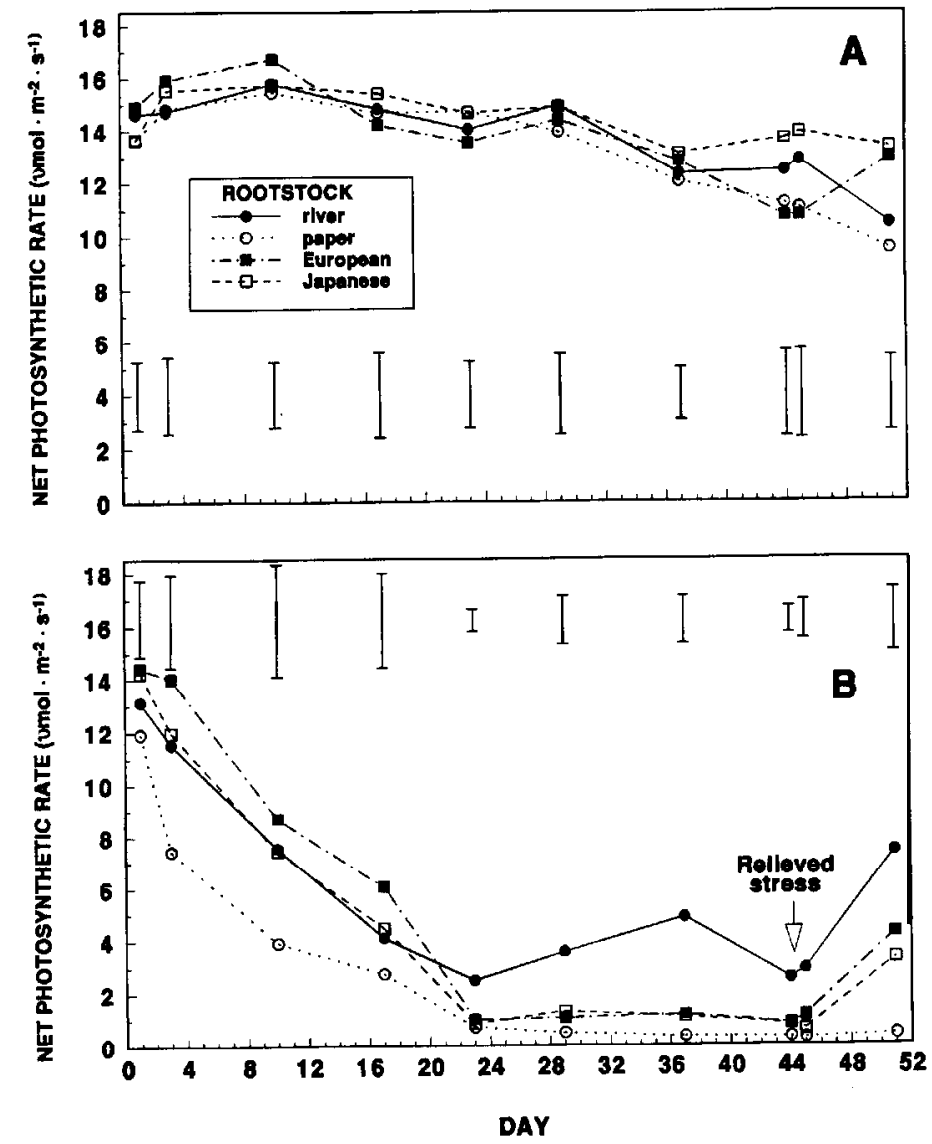

Fig. 1. Net photosynthesis for control (A) and flooded (B) plants measured during Fall 1991. Data points are means with $\mathrm{n}=5$. Vertical bars represent $\mathrm{LSD}_{0.05}$ among graft combinations on a given day. Flooded plants were inundated on day 0 . 

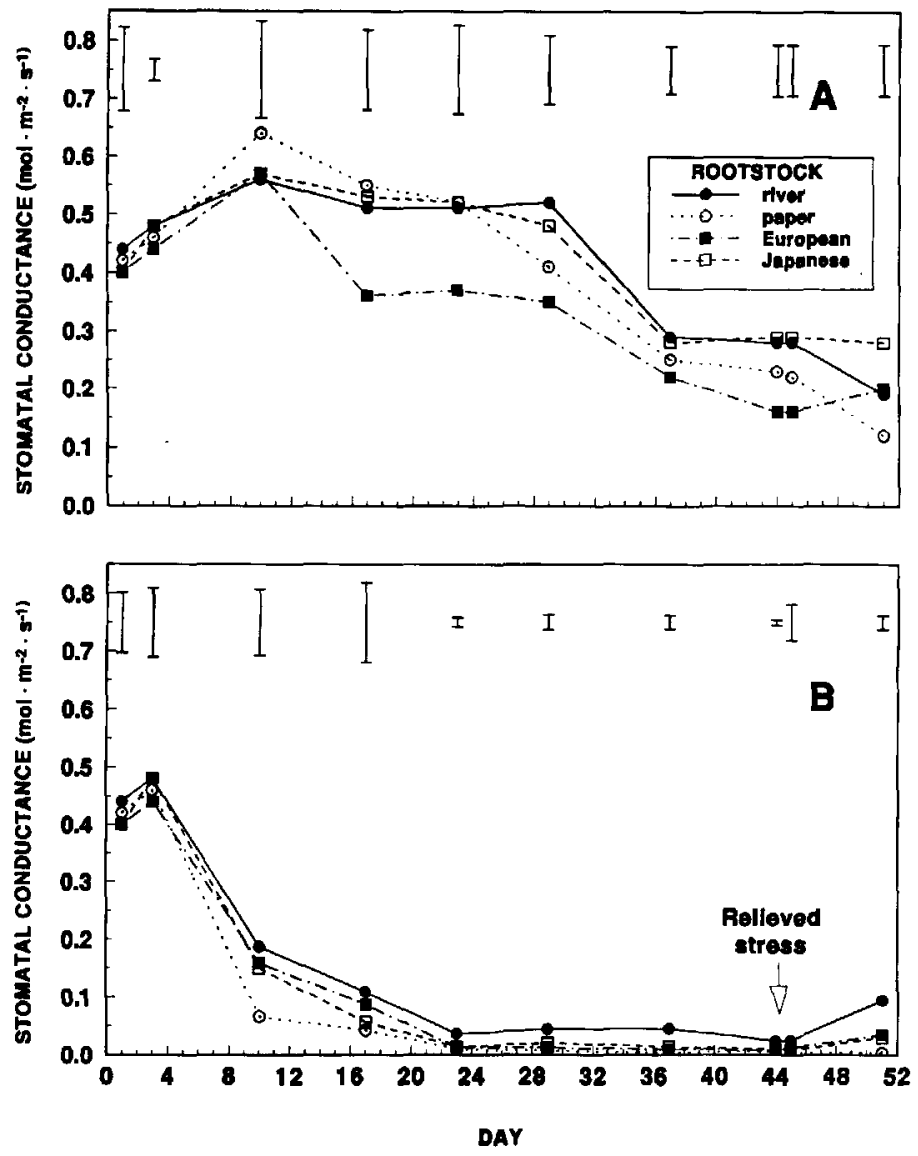

Fig. 2. Stomatal conductance to water vapor for control (A) and flooded (B) plants measured during Fall 1991. Data points are means with $n=5$. Vertical bars represent $\mathrm{LSD}_{0.05}$ among graft combinations on a given day. Flooded plants were inundated on day 0 .

treatment period, yet the stem tissue under the bark was typically green. All plants were subsequently over-wintered so that survival could be determined when plants resumed growth the next spring. All of the control plants and the flooded plants with river and European birch rootstock survived the over-wintering period. Flooded plants on Japanese and paper birch rootstock, however, had similar but significantly reduced survival of $70 \%$ and $60 \%$, respectively (chi-square, $\boldsymbol{P}<0.05$ ).

Mean shoot lengths, 45 days after the control plants were returned to the greenhouse, of plants with European and Japanese birch rootstock were greater than those of the other two graft combinations (Table 1). Mean shoot lengths of the surviving flooded plants, compared as percent inhibition relative to the controls, resulted in the following ranking from least to most growth inhibition: river $<$ (European= Japanese) $<$ paper.

Spring study. $\mathrm{P}_{\mathrm{n}}$ for control plants fluctuated some during the study. However, as was found in the fall study, there were no consistent differences in $\mathrm{P}_{\mathrm{n}}$ among the graft combinations (Fig. 4A). Flooding initially reduced $\mathrm{P}_{\mathrm{n}}$ for all graft combinations. As flooding continued, the severity of the response varied among graft combinations. Plants with paper birch rootstock consistently showed the greatest inhibition, and $\mathrm{P}_{\mathrm{n}}$ eventually decreased to near 0. Plants on European and Japanese birch rootstock showed intermediate responses, while plants on river birch rootstock maintained the highest $\mathrm{P}_{\mathrm{n}}$ rates after 25 days of flooding. Once flooding ended, $\mathrm{P}_{\mathrm{n}}$ increased for some graft combinations, yet plants with river birch rootstock maintained the highest $\mathrm{P}_{n}$ and plants with paper birch rootstock had the lowest $\mathrm{P}_{\mathrm{n}}$.
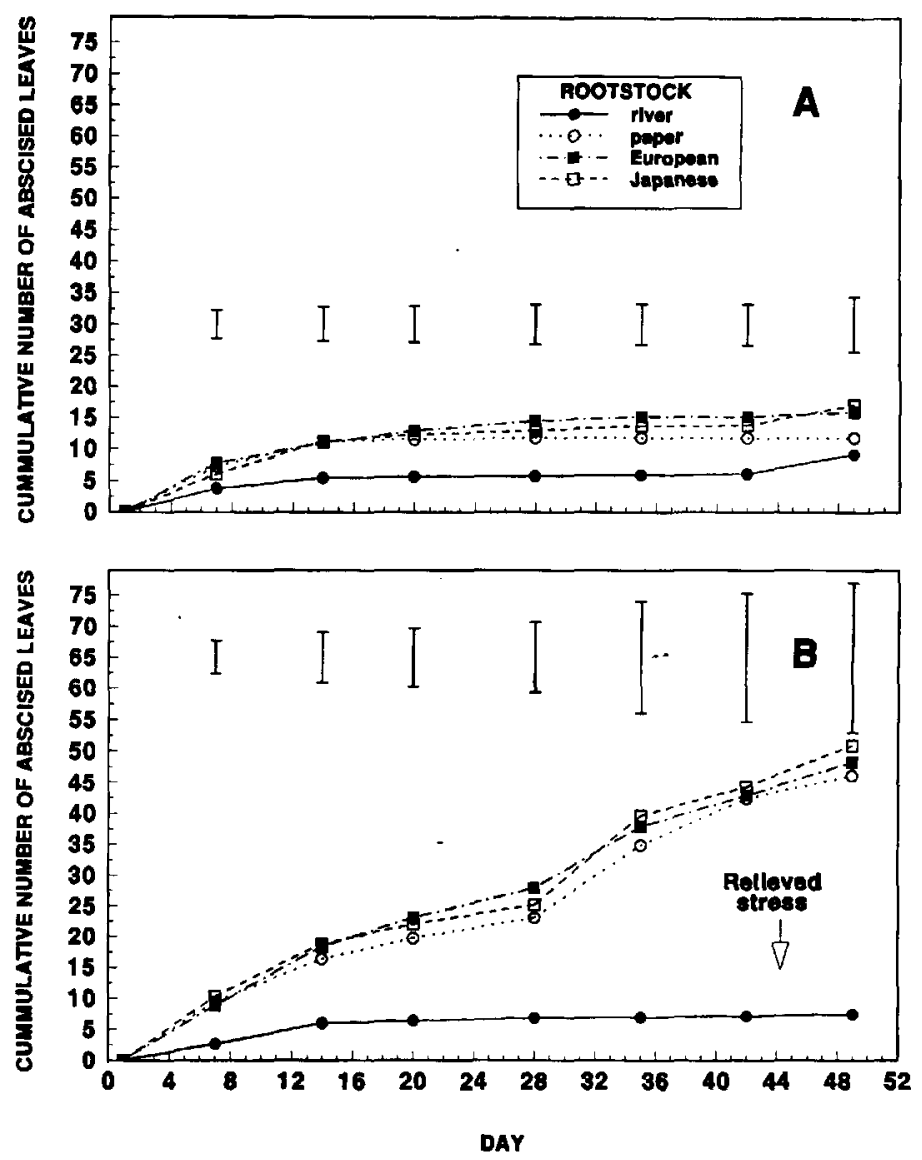

Fig. 3. Cumulative number of abscissed leaves for control (A) and flooded (B) plants recorded during Fall 1991. Data points are means with $n=10$. Vertical bars represent $\mathrm{LSD}_{\mathrm{o} .05}$ among graft combinations at a given point in time. Flooded plants were inundated on day 0 .

Table 1. Mean shoot length measured on 30 Mar. 1992 (45 days after dormant plants were returned to a heated greenhouse) on plants treated the previous fall.

\begin{tabular}{lccc}
\hline \hline & \multicolumn{2}{c}{$\begin{array}{c}\text { Shoot length }^{z} \\
(\mathrm{~mm})\end{array}$} & $\begin{array}{c}\text { Inhibition } \\
\text { Rootstock }\end{array}$ \\
\cline { 2 - 3 } & Control & Flooded & $(\%)$ \\
\hline River & $377 \mathrm{a}$ & $343 \mathrm{a}$ & $9 \mathrm{a}$ \\
Paper & $412 \mathrm{a}$ & $189 \mathrm{~b}$ & $54 \mathrm{c}$ \\
European & $478 \mathrm{~b}$ & $341 \mathrm{a}$ & $29 \mathrm{~b}$ \\
Japanese & $463 \mathrm{~b}$ & $312 \mathrm{~b}$ & $32 \mathrm{~b}$ \\
\hline
\end{tabular}

${ }^{\mathrm{z}}$ Lengths represent means $(\mathrm{n}=10)$, each consisting of three subsamples. Mean separation within columns determined by $\operatorname{LSD}_{0.05}$.

Stomatal conductance of the control plants varied somewhat during the study. There was a trend for plants with river birch rootstock to have one of the highest $g_{s}$ and plants with European birch rootstock to have the lowest $g_{s}$ (Fig. 5A). Stomatal conductance of flooded plants showed trends similar to $\mathrm{P}_{\mathrm{n}}$ (Fig. 5B). As flooding continued, $\mathrm{g}_{\mathrm{s}}$ generally decreased, yet plants with river birch rootstock maintained higher $g_{s}$ than plants on other rootstock during the latter portion of flooding and the subsequent recovery period.

Midday leaf water potentials of the control plants were similar and averaged $-1.15 \mathrm{MPa}$ (Table 2). Flooded plants had higher leaf water potentials, yet, within the flooded treatment, plants on river birch rootstock had significantly lower leaf water potentials than those of other graft combinations. 



Fig. 4. Net photosynthesis for control (A) and flooded(B) plants measured during Spring 1992. Data points are means with $n=5$. Vertical bars represent $L_{S D_{0.05}}$ among graft combinations on a given day. Flooded plants were inundated on day 0 .

Mean shoot growth rates (MSGR) for the control plants decreased during the study, but there was no consistent difference in MSGR among graft combinations (Fig. 6A). MSGR of flooded plants decreased more than MSGR of the control plants (Fig. 6B). Initially, the MSGR of plants with river birch rootstock was among the lowest. However, as flooding continued, MSGR of plants with river birch rootstock became one of the highest and was significantly greater than all other graft combinations after flooding ended.

At the end of the study, control plants on European birch rootstock had lost significantly more leaves than the control plants with river or paper birch rootstock (Fig. 7A). Leaf abscission was more pronounced on many of the flooded plants (Fig. 7B). The ranking of flooded plants from most to least abscissed leaves was paper $>$ Japanese $>$ (European $=$ river). Although some plants were heavily defoliated, all of the trees had at least some green shoots and were considered to be alive at the end of the study.

There were no visible late-formed roots on the stems of any of the rootstock in the control group (Table 2) during the study. River and European birches were the only two rootstock that developed late-formed roots on flooded plants, and plants with river birch rootstock had significantly more of these roots than plants with European birch rootstock.

The density of actively growing root tips on the bottom of the root mass was measured 15 days after flooding ended as an indication of root survival and recovery after flooding. There was no significant difference in root density among the control plants (Table 2). Plants with river birch rootstock had the greatest root-
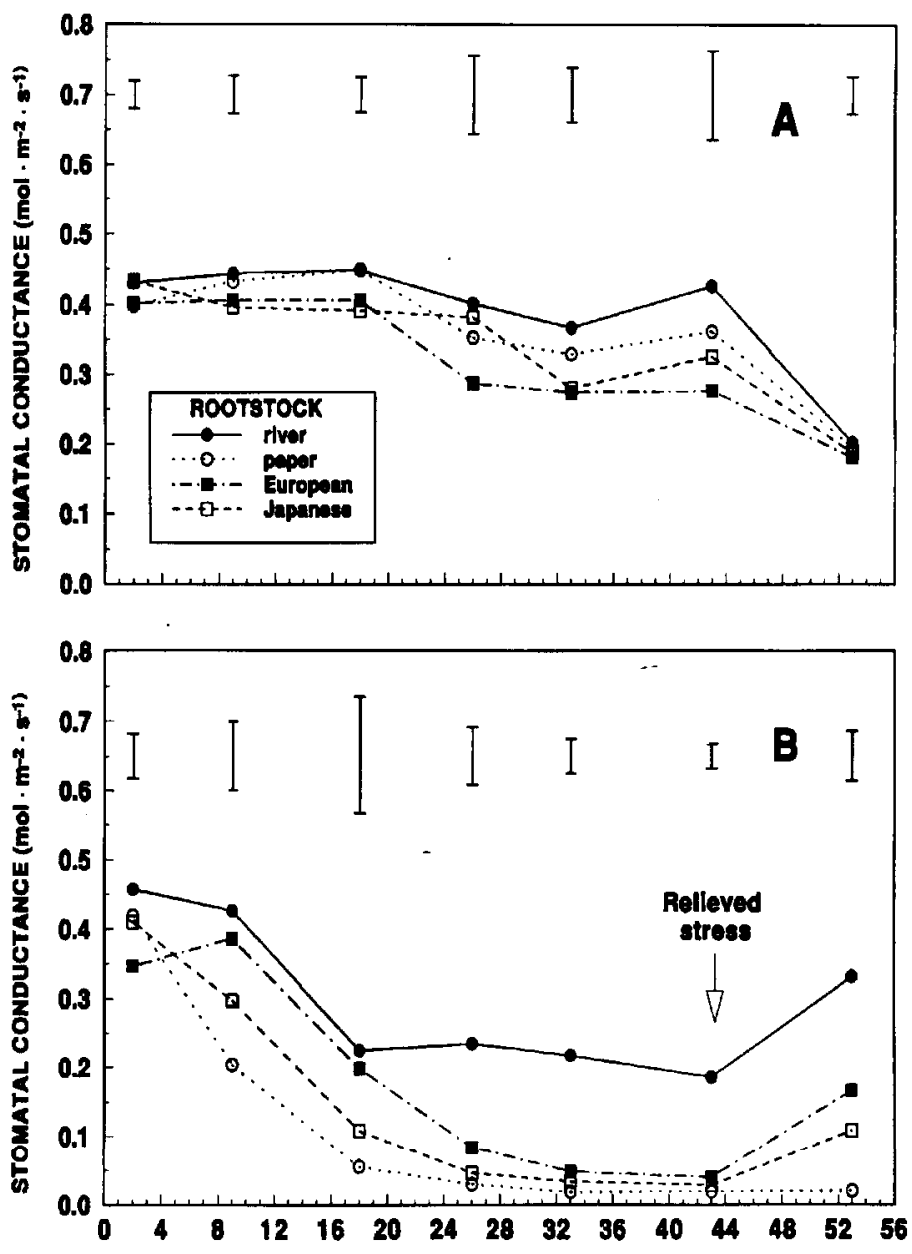

DAY

Fig. 5. Stomatal conductance to water vapor for control (A) and flooded (B) plants measured during Spring 1991, Data points are means with $n=5$. Vertical bars represent $\mathrm{LSD}_{0.05}$ among graft combinations on a given day. Flooded plants were inundated on day 0 .

Table 2. Midday leaf water potential measured on 1 May 1992, number of late-formed roots measured on 11 May 1992, and root-tip density measured on 12 May 1992 of control and flooded plants grown on four rootstocks.

\begin{tabular}{lcccc}
\hline \hline Treatment & Rootstock & $\begin{array}{c}\text { Midday leaf } \\
\text { water potential } \\
(-\mathrm{MPa})\end{array}$ & $\begin{array}{c}\text { No. of } \\
\text { late-formed } \\
\text { roots }\end{array}$ & $\begin{array}{c}\text { Root-tip } \\
\text { density } \\
(\text { no./cm })\end{array}$ \\
\hline Control & River & $1.16^{2}$ & 0 & 0.19 \\
& Paper & 1.06 & 0 & 0.29 \\
& European & 1.18 & 0 & 0.22 \\
Flooded & Japanese & 1.19 & 0 & 0.21 \\
& River & 0.87 & 21 & 0.24 \\
& Paper & 0.58 & 0 & 0.00 \\
& European & 0.43 & 2 & 0.08 \\
& Japanese $^{2}$ & 0.58 & 0 & 0.01 \\
& LSD $_{0.05}$ & 0.26 & 3 & 0.13
\end{tabular}

${ }^{\mathrm{z}}$ Values are means with $\mathbf{n}=\mathbf{5}$ for all variables.

tip density among the flooded plants, while root-tip densities for plants with European, Japanese, and paper birch rootstock were not significantly different from $\mathrm{O}$. 

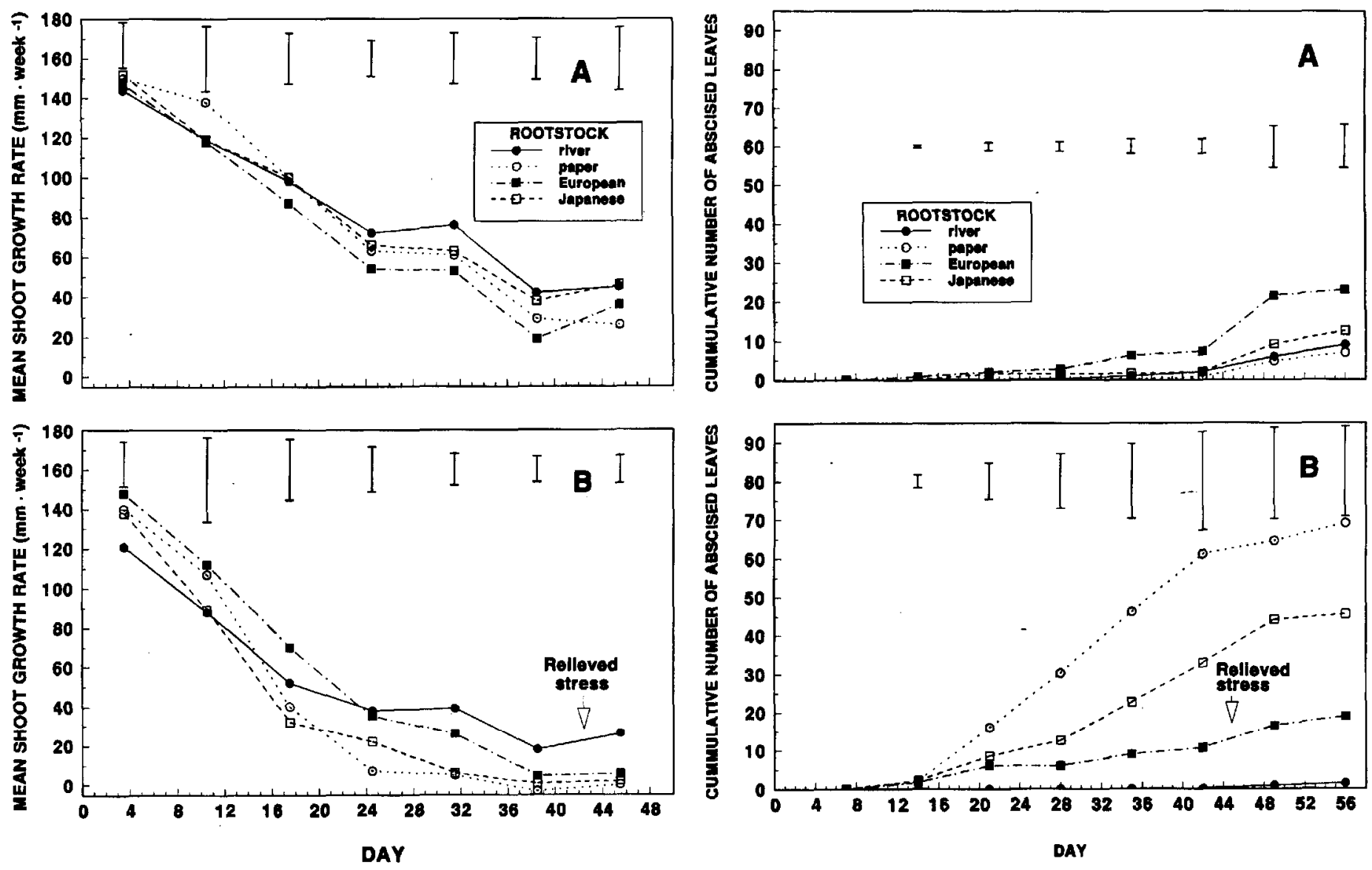

Fig. 6. Mean shoot growth rate for control (A) and flooded (B) plants measured during Spring 1992. Data points are means with $n=5$, Vertical bars represent $\mathrm{LSD}_{0.05}$ among graft combinations for a given period. Flooded plants were inundated on day 0 .

\section{Discussion}

Growth of the control plants appeared normal regardless of rootstock. Growth and physiological measurements were similar among the control plants for all graft combinations, with a few exceptions. Stomatal conductance of European birch was lower than that of some of the other graft combinations on a few dates (Figs. 2A and 5A). However, these differences did not result in lower $\mathrm{P}_{\mathrm{n}}$ for plants on European birch rootstock (Figs. 1A and 4A). Mean shoot length measured after an initial growth period in 1992 (Table 1) showed that plants on river and paper birch rootstock had less shoot growth than plants on European or Japanese birch rootstock. This growth reduction could have been due to a reduction in overall plant growth rate, differences in phenology of growth, or altered partitioning pattems. Three-year-old field-grown plants of the same graft combinations at the Mountain Horticultural Crops Research are also growing well with no symptoms of graft incompatibility (data not shown).

Ranking flood tolerance. River birch was the superior rootstock under flooded conditions. For the plants subjected to prolonged flooding, those on river birch rootstock had among the highest $\mathrm{g}_{\mathrm{s}}$ (Figs, 2B and 5B), $\mathrm{P}_{\mathrm{n}}$ (Figs. 1B and 4B), mean shoot growth rates (Fig. 6B), number of late-formed roots (Table 2), and survival rates. Flooded plants on river birch rootstock also had the lowest percent inhibition of shoot growth after fall flooding (Table 1 ) and the fewest prematurely abscissed leaves (Figs. 3B and 7B). Although plants on European birch rootstock had survival similar to

Fig. 7. Cumulative number of abscissed leaves for control (A) and flooded (B) plants measured during Spring 1992. Data points are means with $n=5$. Vertical bars represent $\mathrm{LSD}_{0 \cdot 05}$ among graft combinations at a given point in time. Flooded plants were inundated on day 0 .

that of plants on river birch rootstock, they did not maintain as high a $\mathrm{P}_{\mathrm{n}}$ under prolonged flooding (Figs. $1 \mathrm{~B}$ and 4B), had fewer late-formed roots (Table 2 ), lower root-tip density after flooding (Table 2), more abscissed leaves (Figs. 3B and 8B), and greater inhibition of shoot growth after flooding ended (Table 1) compared to plants with river birch rootstock. Paper and Japanese birch were the two species most sensitive to flooding and they had the lowest survival rate after flooding. However, plants on paper birch rootstock were the only plants that did not show significant increases in $\mathrm{P}_{n}$ when flooding ended (Figs. $1 \mathrm{~B}$ and 4B), had the greatest inhibition of shoot growth in the spring after the previous season's flooding (Table 1), and had the most prematurely abscissed leaves during spring flooding (Fig. 7B). Based on these results, the following ranking of flood tolerance from most to least is river $>$ European $>$ Japanese $>$ paper. This ranking is specific to the genotypes included in this experiment. Variation in tolerance within a species can be expected.

Flooded plants grown on river birch rootstock often had higher $\mathrm{g}_{\mathrm{s}}$ and $\mathrm{P}_{\mathrm{n}}$ rates, which may have contributed to their superior growth and survival during and after flooding. The variation in $g_{s}$ and $\mathrm{P}_{\mathrm{n}}$ among leaves of 'Whitespire' scions on different rootstock may have resulted from chemical or hydraulic consequences of the rootstock. Plants on river birch rootstock had lower leaf water potentials, yet maintained a higher $g_{s}$ than plants with other rootstock (stated conversely, the lower leaf water potential may have resulted from greater $\mathrm{g}_{\mathrm{s}}$ ). Thus, evidence suggests that the reduced $g_{s}$ of plants on the other rootstock was not due to direct 
effects of greater water deficit stress (lower leaf water potentials) that would typically result from limitations in hydraulic conductance of the rootstock. In many cases, leaf water potential of flooded plants has been higher or similar to that of nonflooded plants, yet $\mathrm{g}_{\mathrm{s}}$ of the flooded plants was reduced (Kozlowski and Pallardy, 1984; Pereira and Kozlowski, 1977). The greater $\mathrm{g}_{\mathrm{s}}$ of plants on river birch rootstock may have resulted from different substances produced by or translocated from the roots. Increased abscissic acid and decreased gibberellins, cytokinins, and $\mathrm{K}^{+}$have been implicated in reducing $\mathrm{g}_{\mathrm{s}}$ of flooded plants (Bradford and Yang, 198 1; Jackson, 1987; Kozlowski and Pallardy, 1984).

The development of late-formed roots during flooding and greater root-tip density after flooding ended indicated a greater tolerance or avoidance of root hypoxia by river birch, and to a lesser extent European birch, rootstock. The development of late-formed roots is a common response to flooding among plants that are adapted well to flooding (Kawase, 1981). Late-formed roots are typically more efficient in conducting $\mathrm{O}_{2}$ from aerial portions of the plant due to the presence of aerenchyma tissue and the closer proximity of the roots to the above-water portions of the stem (Jackson and Drew, 1984; Kawase, 1981). In addition to the diffusion of air from aerial portions of the plant to the roots, pressurized gas transport has been found to improve $\mathrm{O}_{2}$ supply to roots in B. pubescens J.F. Ehrh. (Grosse, et al., 1992), a close relative of European birch. This adaptive mechanism could be important for river and European birches as well. The greater roottip density of river birch rootstock after flooding suggested that river birch roots may also be more tolerant of hypoxic conditions. Tripepi and Mitchell (1984) found that alcohol dehyrogenase activity in river birch roots increased 25-fold after 6 days of hypoxia, whereas there was no change in activity of European birch roots. Such a change in enzyme activity indicates that river birch has metabolic adaptations that may contribute to superior flood tolerance.

The influence of the river birch rootstock on drought resistance of the 'Whitespire' scion is not known. However, using river birch as a rootstock will not necessarily compromise the drought resistance of 'Whitespire' birch. Comparisons of pear rootstock have found Pyrus betulaefolia Bunge. to be flood tolerant (Andersen et al., 1984) and drought resistant (California Agricultural Experiment Station, 1961 ). Similarly, rough lemon (Citrus jambhiri Lush.) was regarded as a flood-tolerant and drought-resistant rootstock for citrus (Ford, 1969; Phung and Knipling, 1976). Many of the characteristics of 'Whitespire' that seem to be important in conferring drought resistance related to the ability of the leaves to maintain turgor and $\mathrm{P}_{\mathrm{n}}$ at low tissue water potentials (Ranney et al., 199 1). The greater capacity of river birch roots to tolerate flooding and hypoxic soils could result in a deeper and more extensive root system, particularly on poorly drained soils, and thereby enhanced drought resistance and flood tolerance of the 'Whitespire' scion. Further, drought resistance of the foliage can be important in conferring flood tolerance. Hosner and Bovce ( 1962), after studving 17 woody species for tolerance to waterlogging, concluded that drought resistance of the leaves was an important characteristic of flood-tolerant species. The combination of a 'Whitespire' scion on a river birch rootstock may therefore improve flood tolerance over that of river birch on its own roots.

This research demonstrated that there is considerable variation in flood tolerance of birch rootstock. Grafting 'Whitespire' Japanese birch onto river birch rootstock (and to a lesser degree
European birch roostocks) enhanced plant growth and survival compared to those of plants on Japanese birch rootstock. Using superior birch rootstock can thereby enhance stress tolerance of 'Whitespire' Japanese and possibly other birch species when grown on poorly drained soils.

\section{Literature Cited}

Andersen, P. C., P.B. Lombard, and M.N. Westwood. 1984. Leaf conductance, growth, and survival of willow and deciduous fruit tree species under flooded soil conditions. J. Amer. Soc. Hort. Sci. 109: 132-138.

Bradford, K.J. and S.F. Yang. 1981. Physiological responses of plants to water logging. HortScience 16:25-30.

California Agricultural Experiment Station. 1961. Pear rootstock in California. California Agr. Expt. Sta. Ser. Lflt. 136.

Ford, H.W. 1969. Water management of wetland Citrus in Florida. Proc. 1st Intl. Citrus Symp. 3:1759-1770.

Grosse, W., J. Frye, and S. Lattermann. 1992. Root aeration in wetland trees by pressurized gas transport. Tree Physiol. 10:285-295.

Harlow, W. M., E.S. Harrar, and F.M. White. 1979. Textbook of dendrology. 6th ed. McGraw-Hill, New York.

Hasselkus, E. 1984. Introducing Betula platyphylla 'Whitespire'. Arnoldia 44:36-38.

Hosner, J.F. and S.G. Boyce. 1962. Tolerance to water saturated soil of various bottomland hardwoods. For. Sci. 8:180-186.

Jackson, M.B. 1987. A structured evaluation of the involvement of ethylene and abscissic acid in plant reponses to aeration stess, p. 189-199. In: G.V. Hoad, J.R. Lenton, M.B. Jackson, and R.K. Atkin (eds.). Hormone action in plant development. A critical appraisal. Butterworths, Boston.

Jackson, M.B. and M.C. Drew. 1984. Effects of flooding on herbaceous plants, p. 47-128. In: T.T. Kozlowski (cd.). Flooding and plant growth. Academic Press, New York.

Kawase, M. 1981. Anatomical and morphological adaptation of plants to water logging. HortScience 16:30-33.

Kozlowski, T.T. and S.G. Pallardy. 1984. Effects of flooding on water, carbohydrate, and mineral relations, p. 165-193. In: T.T. Kozlowski (cd.). Flooding and plant growth. Academic Press, New York.

Larson, K. D., B. Schaffer, and F.S. Davies. 1991. Flooding, leaf gas exchange, and growth of mango in containers. J. Amer. Soc. Hort. Sci. 116:156-160.

McKim, H. L., L.W. Gratta, and C.J. Merry. 1975. Inundation damage to vegetation at selected New England flood control reservoirs. U.S. .Army Cold Regulat. Res. and Eng. Lab., Hanover, New Hampshire.

Norby, R.J. and T.T. Kozlowski. 1983. Flooding and $\mathrm{SO}_{2}$ stress interaction in Betula papyrifera and B. nigra seedlings. For. Sci. 29:739-750.

Pereira, J.S. and T.T. Kozlowski. 1977. Variations among woody angiosperms in response to flooding. Physiol. Plant. 41:184-192.

Phung, H.T. and E.B. Knipling. 1976. Photosynthesis and transpiration of Citrus seedlings under flooded conditions. HortScience 11:131-133.

Ranney, T. G., R.E. Bir, and W.A. Skroch. 1991. Comparative drought resistance among six species of birch (Betula): Influence of mild water stress on water relations and leaf gas exchange. Tree Physiol. 8:351-360.

Sojka, R.E. and L.H. Stolzy. 1980. Soil-oxygen effects on stomatal response. Soil Sci. 130:350-358.

Tang, Z.C. and T.T. Kozlowski. 1982. Some physiological and growth responses of Betula papyrifera seedlings to flooding. Physiol. Plant. 55:415-420.

Tang, Z.C. and T.T. Kozlowski. 1983. Further studies in flood tolerance of Betula papyrifera seedlings. Physiol. Plant. 59:218-222.

Tripepi, R.R. and C.A. Mitchell. 1984. Metabolic response of river birch and European birch roots to hypoxia. Plant Physiol. 76:31-35.

Tsukahara, H. and T.T. Kozlowski. 1986. Effect of flooding and temperature regime on growth and stomatal resistance oBetula platyphylla var. japonica seedlings. Plant\& Soil 92:103-112.

Weaver, Jr., R.E. 1978. The ornamental birches. Arnoldia 38: 117-131. 